\title{
Thermoablatiós lehetőségek a benignus térfoglaló képletek gyógyításában
}

\author{
Deák Pál Ákos dr. - Korda Dávid Ádám dr. - Doros Attila dr.
}

Semmelweis Egyetem, Általános Orvostudományi Kar, Transzplantációs és Sebészeti Klinika, Budapest

\begin{abstract}
Bevezetés: Bizonyos jóindulatú tumorok méretükből és elhelyezkedésükből fakadóan tartós diszkomfort érzést, súlyosabb esetben rupturálva végzetes kimenetelú vérzést is okozhatnak. Megoldásként eddig a daganatok obszervációja, indokolt esetben a sebészeti beavatkozás, válogatott esetekben pedig a transarterialis embolisatio adódott. Célkituzés: Célkitüzésünk az volt, hogy ismertessük a jóindulatú elváltozások thermoablatiós kezelési lehetőségeit. Módszer: A Semmelweis Egyetem Transzplantációs és Sebészeti Klinikáján kezelt négy betegen végzett beavatkozásokat ismertetjük. Egy esetben pajzsmirigy-adenoma, egyben vese-angiomyolipoma kezelése történt rádiófrekvenciás készülékkel, két betegnél pedig májhaemangioma-ablatióra került sor mikrohullámú antenna segítségével. Eredmények: A kezelés minden esetben szövődménymentesnek bizonyult, a kontrollvizsgálatoknál a legtöbb elváltozás mérete csökkent. Az átlagos volumencsökkenés $32,7 \%$ volt. A kezelés hatására az elváltozások kontrasztanyag-halmozása is csökkent. A halmozást mutató tumortérfogat-csökkenés átlagosan 75,3\% volt. Következtetések: A thermoablatiós módszerek a fent említett benignus szöveti természetű daganatok esetében biztonsággal alkalmazhatók, az eljárás technikájából fakadóan kiváló kozmetikai eredménnyel, rövidebb kórházi benntartózkodással és lábadozási idővel járnak. Orv. Hetil., 2016, 157(51), 2040-2047.
\end{abstract}

Kulcsszavak: intervenciós radiológia, ablatio, benignus tumor

\section{Thermoablation therapy in the treatment of benign lesions}

Introduction: Depending on their size and location, some benign tumors can cause prolonged discomfort and even rupture and fatal bleeding in severe cases. Hitherto the therapeutic strategies for such lesions were observation, surgery and in selected cases transarterial embolization. Aim: Our aim was to present the possibilities of thermoablation for treating lesions. Method: Here we present interventions of four patients in Semmelweis University Department of Transplantation and Surgery. A thyroid adenoma and a kidney angiomyolipoma were treated with radiofrequency ablation. Two patients with a liver haemangioma were treated with microwave thermoablation technique. Results: Complications were not observed in any of the cases. In most cases, the size of the treated lesions decreased. The mean decrease in volume was $32.7 \%$. The contrast enhancement of the lesions also decreased, the mean reduction in contrast enhancing volume was $75.3 \%$. Conclusions: Thermoablational procedures for the benign tumors presented above are safe. The therapy shows excellent cosmetic results, a shorter hospital stay and quicker recovery.

Keywords: interventional radiology, ablation, benign tumors

Deák, P. Á., Korda, D. Á., Doros, A. [Thermoablation therapy in the treatment of benign lesions]. Orv. Hetil., 2016, $157(51), 2040-2047$.

(Beérkezett: 2016. augusztus 3.; elfogadva: 2016. október 21.)

\section{Rövidítések}

MWT = mikrohullámú ablatio; OEP = Országos Egészségbiztosítási Pénztár; RFA = rádiófrekvenciás ablatio; TACE $=$ transarterialis chemoembolisatio; TAE = transarterialis embolisatio

Intézetünkben, a Semmelweis Egyetem Transzplantációs és Sebészeti Klinikáján nagy számban végzünk rosszindulatú máj- és vesetumorok esetében, valamint me- tasztázisoknál a transarterialis embolisatiós (TAE) és transarterialis chemoembolisatiós (TACE) kezelések mellett rádiófrekvenciás ablatiós (RFA) és mikrohullámú ablatiós (MWT) kezeléseket kuratív és palliatív célból egyaránt. Klinikánkon új indikációként jelent meg a tavalyi évben a vese-angiomyolipoma és a májhaemangioma mellett a jóindulatú, de jelentős panaszt okozó pajzsmirigygöb is. Ez hazánkban is az első ilyen beavatkozás volt. A továbbiakban az utóbbi négy benignus eltérés 
intézetünkben történt kezelését ismertetjük. Mivel ezeknek a jóindulatú elváltozásoknak a kezelése jelenleg nem finanszírozott, a beavatkozások elvégzéséről az intézet vezetésének bevonásával a sebész és az intervenciós radiológus dönt. A radiológiai intervenciókra a betegek tájékozott beleegyezését követôen a radiológia részleg intervenciós laborjában került sor.

A rádiófrekvenciás és mikrohullámú ablatio, a transarterialis embolisatio, chemoembolisatio manapság széles körben elfogadott és alkalmazott módja a malignus daganatok kezelésének [1]. Az invazív radiológia fejlődésével ezek a technikák egyre inkább teret nyernek nemcsak az onkológiai betegek kezelésében, hanem bizonyos jóindulatú térfoglaló képletek esetében is [2]. A máj rosszindulatú daganatainak RFA-kezelése hazánkban is ismert és alkalmazott eljárás [3]. Az MWT-kezelés, mint szintén hőablatiós módszer, az utóbbi években kezd elterjedni ezen a területen [4]. Hasonlóságai mellett (úgymint az ablatio sikeressége, hosszú távú túlélés, alacsony szövődményráta) ennek az eljárásnak előnyei is vannak az RFA-val szemben. Mivel a kezelt szövet kiszáradása és szenesedése kevésbé befolyásolja a kezelés hatékonyságát, valamint az erek hűtőhatása kevésbé érvényesül a laesiók kezelésekor, ezért az MWT az RFA-hoz viszonyítva gyorsabban kivitelezhető [5].

A klinikánkon kezelt betegek átlagéletkora 34,5 év volt. A beavatkozásokat általános anesztéziában, ultrahangvezérelten végeztük. Két betegnél óriáshaemangioma MWT-kezelése történt, egy esetben vese-angiomyolipoma RFA-, egyben pedig pajzsmirigygöb RFA-kezelésére került sor. Az MWT-kezeléseket MicroThermX készülékkel (BSD Medical Corp., Salt Lake City, UT, 84119, Amerikai Egyesült Államok), az RFAkezeléseket Rita Starbust (AngioDynamics, Inc., Manchester, GA 31816, Amerikai Egyesült Államok) készülékkel végeztük.

A kezelések hatásosságának vizsgálata retrospektív módon történt, a páciensek kontroll képalkotó vizsgálatainak áttekintésével. Az átlagos nyomon követési idő 7,8 hónap volt. A kezelés előtti és az azt követó kontroll képalkotó vizsgálatokon megmértük az elváltozások, valamint azok halmozást mutató komponensének legnagyobb átmérőit a tér három síkjában. A kapott értékek alapján meghatároztuk a tumortérfogat, valamint a halmozást mutató térfogat kezelés hatására bekövetkezó százalékos változását.

\section{Óriáshaemangioma MWT-kezelése}

\section{Általános megfontolások}

Általánosan ismert és elfogadott tény, hogy a jóindulatú, szolid májelváltozások nagy számban fordulnak elő a populációban [6]. Közülük a legismertebbek (a cisztán kívül) a cavernosus haemangioma, az angiomyolipoma, az adenoma, a follicularis nodularis hyperplasia és a haemangioendothelioma. A benignus eltérések számának növekedése nemcsak életmódunk változásának tulajdonítható, korai felismerésük finomodó diagnosztikai lehetőségeinek is köszönhető [7]. Az egyre nagyobb információtartalommal bíró képi diagnosztikai módszerek pontosabb képet adnak a daganatok természetéról is, így határozottabb, személyre szabottabb ajánlások fogalmazhatók meg különböző betegségek kezelésére vonatkozóan. A jóindulatú körülírt májelváltozások esetében a képalkotó vizsgálatokkal végzett rendszeres kontroll a leggyakrabban követett stratégia [8]. A sebészi vagy intervenciós radiológiai kezelések megkezdéséhez egyértelmü, tumorspecifikus tünetek, esetleg a daganat jellegéből, térfoglaló hatásából származó szövődmények fennállása szükséges [9].

Jóindulatú májtumorokról lévén szó, kiemelt figyelmet kell fordítanunk a pontos indikációs körre és a kontraindikációkra is. A javallatok köre magában foglalja [10, 11]:

- a kétes megjelenésû́ elváltozásokat, amelyek egyértelmú malignitását nem lehet bizonyítani (biopszia után sem) - különös tekintettel azokra az esetekre, amikor a kórtörténetben rosszindulatú daganat szerepel, esetleg hepatitis B- vagy C-vírus-fertőzés áll fenn, cirrhosissal vagy a nélkül;

- ha a jóindulatú terime féléves kontrollnál $\mathrm{l}$ cm-nél többet nőtt legnagyobb átmérójében;

- a malignizálódásra való hajlamot (például adenoma);

- ha a beteg egyértelmúen a térfoglaló képlet okozta tïnetektől szenved (helyi fájdalom, diszkomfort, nyomási tünetek);

- ha a beteg számára a véletlenül felfedezett képlet jelentős pszichés megterhelést jelent (különösen pozitív rosszindulatú daganatos anamnézis esetén).

A kontraindikációk között szerepel:

- a súlyos szervi elégtelenség (szív, máj, tüdő stb.);

- a jelentôs, nem korrigálható véralvadási zavar (PI>30 s, $40 \%$ alatti protrombin, $30000 / \mathrm{ml}$ alatti thrombocytaszám);

- ha heveny gyulladás, aktív fertőzés áll fenn;

- ha az elváltozást nem lehet biztonsággal ábrázolni az intervenció vezérlésére választott képalkotó módszerrel.

\section{Esetbemutatások}

\section{Elsö beteg}

A 34 éves nóbeteg 2011-ben hasi panaszok kivizsgálása céljából végzett ultrahangvizsgálata során derült fény májhaemangiomatosisára. A 2011-ben készült ultrahangvizsgálat során a legnagyobb elváltozás $23 \mathrm{~mm}$-es volt, amelynek mérete 2015-ben már meghaladta a 8 $\mathrm{cm}-t$. Mivel az elváltozás a máj jobb lebenyének centrális részére lokalizálódott, több májszegmentumot is érintett, ezért sebészi eltávolításra nem volt alkalmas. A további méretbeli növekedés megakadályozása céljából 2015 júniusában transarteriás embolisatiós (TAE) keze- 


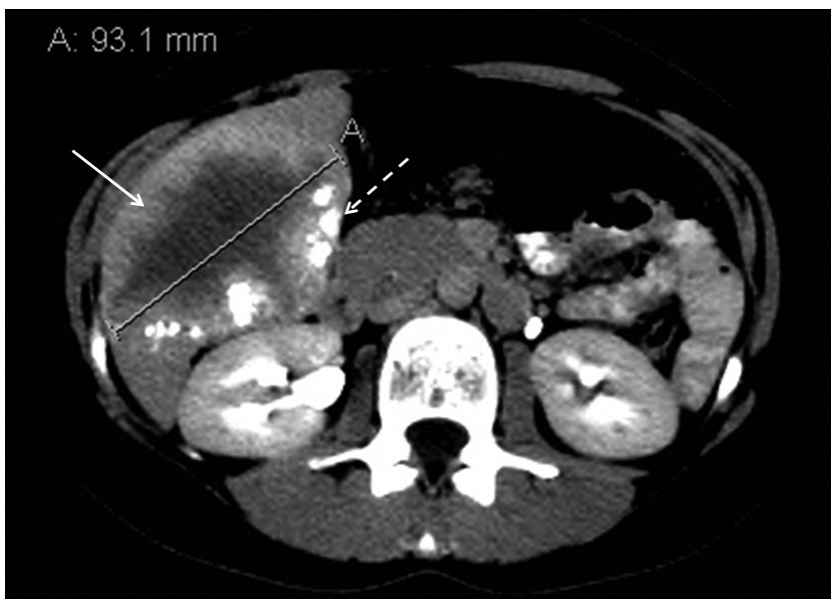

1. ábra

A késői fázisú, axiális síkú CT-felvételen a máj jobb lebenyének caudalis részét csaknem teljes egészében kitöltő, haemangiomára jellemző kontrasztanyag-halmozási dinamikát mutató képlet látható. Az elváltozás széli részén sávszerű kontrasztanyag-halmozás figyelhető meg (fehér nyíllal jelölve), emellett dorsome dialis szélénél Lipiodol-akkumuláció jelei láthatók (szaggatott nyíllal jelölve) a korábbi TAE-kezelés eredményeképpen

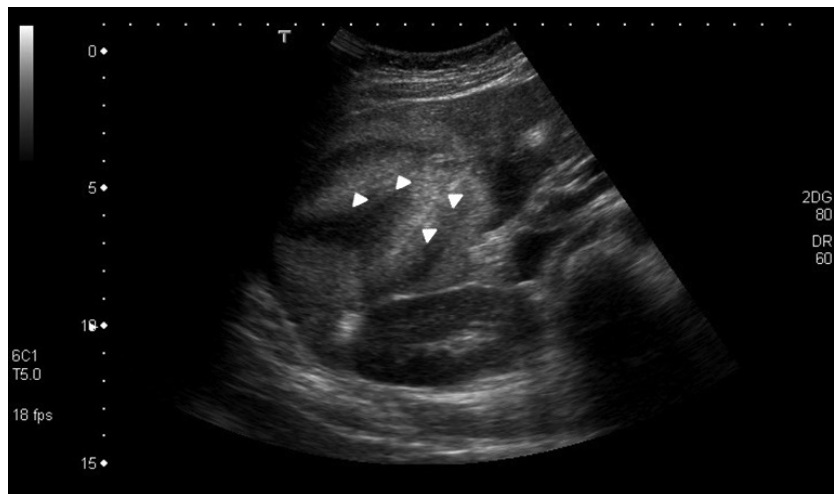

2. ábra

Az MWT-kezelést követő kontroll hasi ultrahangvizsgálaton megfigyelhetôk az ablatiós tû szúrcsatornái (fehér nyílhegyekkel jelölve) és a körülöttük lévő ablatiós zónák. Szövődményre utaló eltérés nem látható

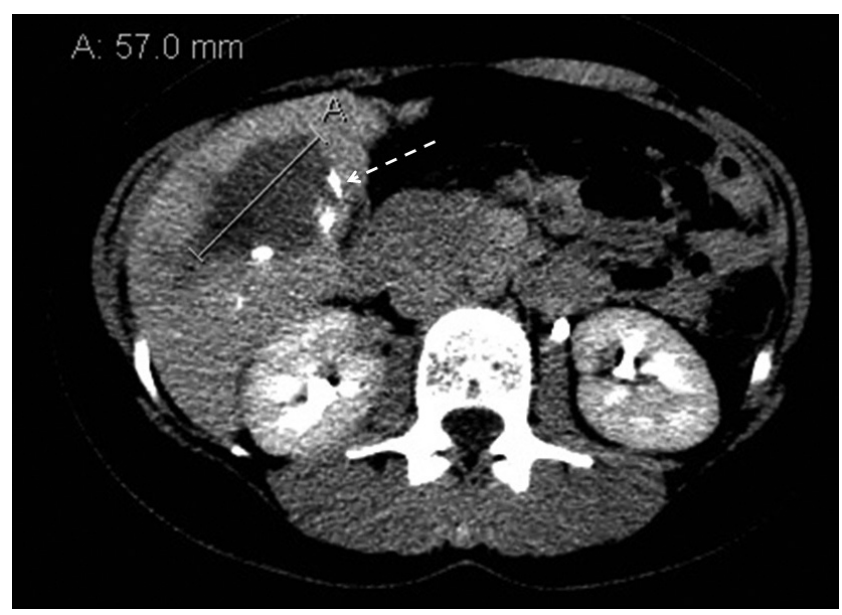

3. ábra

Az ablatiós kezelést követően hat hónappal készült késői fázisú, axiális síkú CT-felvételen méretbeli regresszió figyelhető meg. A kezelt elváltozáson belül érdemi kontrasztanyag-halmozás nem detektálható. A képlet dorsomedialis szélénél, hasonlóan a korábbi vizsgálathoz, Lipiodol-depozitumok láthatók (szaggatott nyíllal jelölve) lésre került sor. Ennek során a centrálisan elhelyezkedő óriáshaemangioma, valamint két kisebb elváltozás szuperszelektív lipiodolos kezelése történt. A 2015 októberében végzett kontroll hasi CT-vizsgálat során a kisebb haemangiomás gócok teljes, az óriáshaemangioma részleges embolisatióját véleményezték (1. ábra). 2015 decemberében az óriáshaemangioma MWT-kezelésére került sor. Tekintettel az elváltozás nagy méretére, az ablatio több síkból történt. A beavatkozást követő ultrahangvizsgálat során szövődményre utaló eltérés nem volt kimutatható (2. ábra). A 2016. júniusi kontroll-CT-vizsgálat nagyfokú méretbeli regressziót és csak minimális mértékú széli kontrasztanyag-betelődést mutatott az elváltozáson belül (3. ábra). A kezelés hatására a tumortérfogat 64\%-kal, a halmozó térfogat 95\%-kal csökkent.

\section{Második beteg}

A 32 éves nőbeteg terhessége közben jelentkező hasi panaszok kivizsgálása céljából 2013 áprilisában ultrahangvizsgálatot végeztek, amelynek során májának II-es szegmentumában egy $6 \mathrm{~cm}$-es, V-VI. szegmentumában egy $11 \mathrm{~cm}$ legnagyobb átmérőjü, májfelszínig érő haemangiomát írtak le (4. ábra). A haemangiomák rupturájának veszélye miatt terhessége 37 . hetében elektív császármetszés történt, egészséges újszülött jött világra. Kontroll-ultrahangvizsgálatok során a haemangiomás gócok mérsékelt növekedése volt megfigyelhető. A haemangiomák további növekedésének gátlása és az esetleges szövődmények megelőzése céljából 2014 májusában embolisatiós kezelés történt, amelynek során az elváltozásokat ellátó artériákba szuperszelektív kanülizációt követően Lipiodolt juttattak be. A kontroll-MR-vizsgálatok során a gócok kismértékű növekedését írták le, emiatt 2014 októberében, majd 2015 májusában ismételt embolisatiós kezelésekre került sor. Mivel ezek a kezelések sem hozták meg a várt eredményt, 2016 áprilisá-

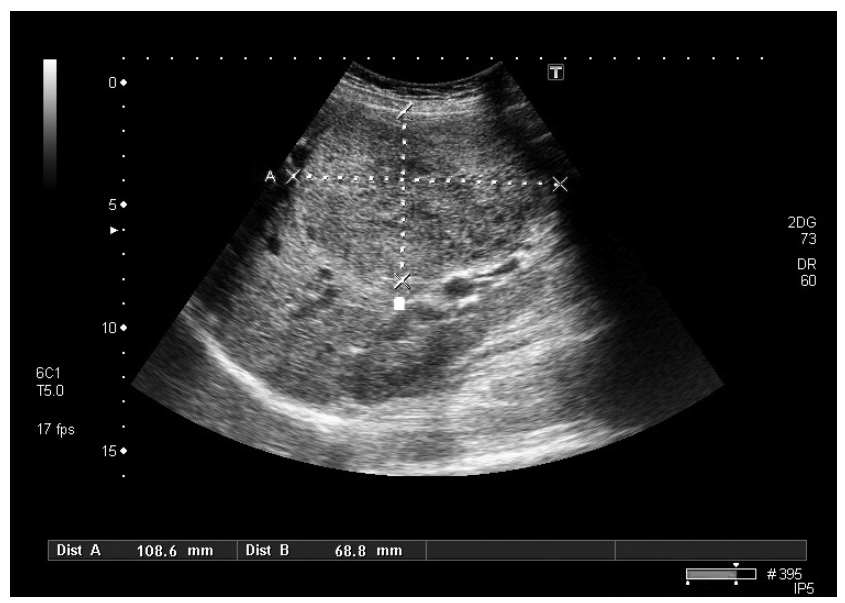

4. ábra $\quad$ A hasi ultrahangvizsgálaton a máj jobb lebenyében lévő óriáshaemangioma ábrázolódik 


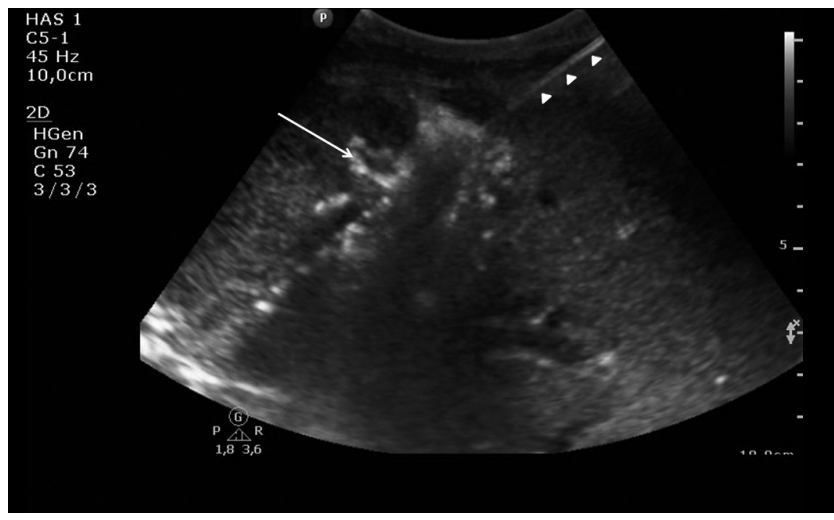

5. ábra $\mid$ A máj jobb lebenyében lévő óriáshaemangioma ultrahangvezérelt, percutan MWT-kezelése. Megfigyelhető az elváltozás centrumába vezetett ablatiós antenna (fehér nyílhegyekkel jelölve) és a hőhatás eredményeként képződő gázbuborékok (fehér nyíllal jelölve)

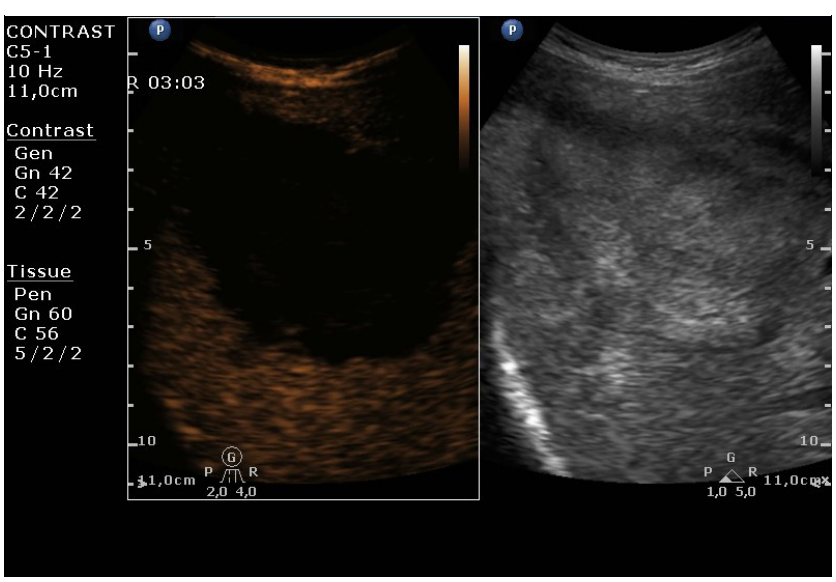

6. ábra $\mid$ MWT-kezelést követő háromhetes kontroll-ultrahangvizsgálat A késői fázisú CEUS-vizsgálaton a kezelt elváltozás területén kontrasztanyag-halmozás nem detektálható

ban mindkét elváltozás percutan MWT-kezelése történt (5. ábra). Az ezt követő kontrasztanyagos ultrahang(CEUS-) vizsgálat a kezelt óriáshaemangiomák csaknem teljes devascularisatióját mutatta (6. ábra). A nagyobb méretü elváltozás 29,9\%-os, a kisebb méretü elváltozás 16,1\%-os térfogatcsökkenést mutatott. A halmozó térfogat csökkenése mindkét elváltozás esetén $98 \%$ volt.

\section{Óriás-angiomyolipomák thermoablatiós kezelése}

\section{Általános megfontolások}

A jóindulatú vesedaganatok mind klinikai, mind pedig szövettani megjelenésüket tekintve heterogén csoportot alkotnak. A 2004-es WHO-besorolás szerint hisztogenetikailag és kórszövettanilag osztályozhatók. A benignus tumorok eszerint vesesejtes, metanephricus, mesenchymalis, valamint vegyes, epithelialis-mesenchymalis eredetúek lehetnek. A leggyakoribb típusok az angi- omyolipoma (AML), az adenoma és az oncocytoma. A fenti csoportból az AML-lel találkozunk legtöbbször, jellegzetesen középkorú nők [12] és sclerosis tuberosában szenvedő gyermekek között [13]. A daganat rendellenes erekből, simaizomsejtekből és zsírból, illetve ezek különböző arányú keverékéből áll. A genetikai eredetű sclerosis tuberosás páciensek mindkét veséjében számos ilyen elváltozás látható, amelyek közül a 3,5-4 cm-esek már panaszt okozhatnak. Ilyenek a tompa fájdalom, véres vizelet és az olykor súlyos kimenetelü retroperitonealis vérzés. A kisebb AML-ek nem szorulnak kezelésre, időszakos követésük elegendő az esetek többségében, azonban a panaszokat okozó képletek kezelési irányelvek rögzítését teszik szükségessé. Mivel jóindulatú elváltozásról van szó, a terápia alapját képezi a nefronok megtartása, a vesefunkció megőrzése a „Primum nil nocere!” elve szerint. Noha a kisebb elváltozások csak akkor igényelnek kezelést, ha panaszt okoznak, a $4 \mathrm{~cm}$ fölötti AML-ek mindenképpen intervencióra szorulnak még akkor is, ha nem járnak tünetekkel, mivel ebben a mérettartományban a ruptura veszélye jelentősen megnő [14]. Az elváltozások hagyományos kezelési módja a sebészi reszekció, esetenként nephrectomia. Az utóbbi évtizedben látható fejlődés lehetővé tette a minimálisan invazív kezelések elterjedését ezen a területen is, a laparoszkópos nefronkímélő parciális reszekció, a transarterialis embolisatiók és a thermoablatiós technikák hazánkban is elérhetők.

Szövettanilag jóindulatú elváltozások lévén az indikációs kör itt is pontosan definiált [15-17]. Eszerint kezelésre szorul:

- a 4 cm-t meghaladó méretü AML;

- a $4 \mathrm{~cm}$ legnagyobb átmérőt el nem érő, de tüneteket (nyomási tünetek, haematuria, retroperitonealis vérzés stb.) okozó AML;

- a 4 cm-t el nem érő, de pszichésen jelentős megterhelést okozó képletek esetén (rupturától, nyitott mútéttől való félelem).

A májnál említett általános kontraindikációkon kívül a vesénél speciális ellenjavallatot képez:

- az üregrendszerbe nyomuló AML;

- a környező szervekbe törő vagy azoktól (vékony- és vastagbélkacsok) el nem választható terime.

\section{Harmadik beteg}

A 16 éves nőbeteg anamnéziséból egyéves kora óta ismert sclerosis tuberosa emelendő ki. Alapbetegsége manifesztációjaként mindkét oldali veséjében többszörös angiomyolipomás elváltozások alakultak ki, amelyeket rendszeres ultrahang-, valamint MR-vizsgálatokkal kontrollálnak. A 2015 novemberében készült MR-vizsgálat során a bal oldali vesében lévő angiomyolipomás gócok növekedését írták le (7. ábra). Mivel a nagyméretú angiomyolipomás gócok esetében magas a vérzéses szövődmények kockázata, intervenciós radiológiai konzíliumra került sor. A konzílium során az elváltozásokat 
alkalmasnak találták percutan ablatiós kezelésre. A Semmelweis Egyetem, Transzplantációs és Sebészeti Klinika Radiológiai Osztályán 2016 márciusában megtörtént a bal vesében elhelyezkedő 58 és $25 \mathrm{~mm}$-es laesiók szövődménymentes rádiófrekvenciás ablatiója RITA Starbust XL készülékkel ( 8 . ábra). Morfológiailag mindkét elváltozás komplett ablatiója volt megfigyelhető. A 2016 júniusában végzett kontroll-MR-vizsgálat a kezelt gócok méretbeli regresszióját és csökkent halmozását mutatta (9. ábra). A nagyobb méretú elváltozás térfogata 28,7\%kal, a kisebb méretű elváltozás térfogata 25,4\%-kal csökkent. A halmozást mutató térfogat csökkenése a nagyobb elváltozás esetében 38,3\%, a kisebb elváltozásnál 45,4\% volt.

\section{Panaszokat okozó pajzsmirigygöb rádiófrekvenciás ablatiója}

\section{Általános megfontolások}

A pajzsmirigygöbök tapintással a népesség 2-6\%-ában, ultrahanggal 19-35\%-ában lelhetők fel irodalmi adatok alapján [18]. Ismert tény, hogy a strúmagöbök nagyobb frekvenciával alakulnak ki jódhiányos területeken élőkben, így a négyötöd részében jódhiányos Magyarországon kifejezetten gyakran fordulnak elő [19]. A göbök 10\%-ban jelentkeznek tünetekkel, négyszer gyakrabban nőkben. Noha a göbök túlnyomó többsége jóindulatú és nem igényel kezelést, bizonyos esetekben a velük járó nyelési, hangképzési zavar, valamint nyaki diszkomfort és kozmetikai okok miatt mégis beavatkozásra van szükség. A nyitott mütétnek számtalan hátulütője lehet, úgymint a hosszas kórházi benntartózkodás, a nehezen elfedhető nyaki heg, a nervus recurrens sérülése, de itt említhető az esetleges későbbi reoperálási nehézség is. A levothyroxin szuppressziós kezelés eredményei - mint a mütét alternatívája - mind a mai napig ellentmondásosak [20], alkalmazása háttérbe szorult. A fentieket figyelembe véve érthető a minimálisan invazív kezelési módszerek térnyerése. Az etanolos infiltráció hazánkban is ismert és alkalmazott eljárás, és a cisztikus göbök esetén kifejezetten hatékonynak mondható. A lézeres ablatio itthon nem került bevezetésre, ennek magyarázata lehet az igen magas költség és az egyéb hőablatiós módszerekhez viszonyított kisebb hatékonyság [21]. A fent említett technikákhoz tartozik a mikrohullámú és a rádiófrekvenciás ablatio. Intézetünkben mindkét technika alkalmazásában kellő gyakorlattal rendelkezünk, ennek fényében az RFA-t választottuk páciensünk kezelésére. Emellett a technika mellett szólt az általunk használt rádiófrekvenciás generátor biztosította szöveti impedanciakontroll, ami közvetlen visszajelzést biztosít a szövetek koagulációjáról, így kezelésünk hatékonyságáról azonnali információt ad.

A pajzsmirigygöbök ablatiója előtt a nemzetközi irodalomnak megfelelő indikációs kört vettük figyelembe [22-25]:

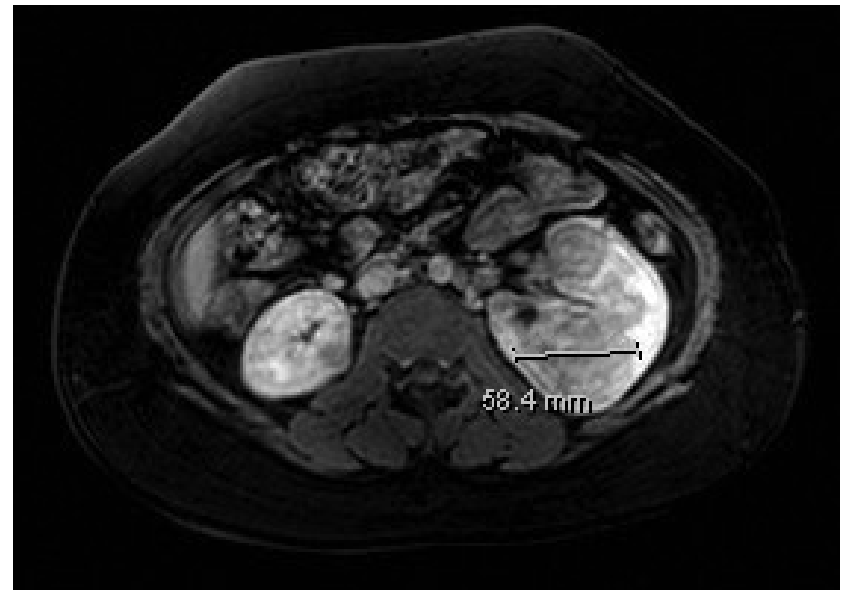

7. ábra $\mid$ Az MR-vizsgálaton a posztkontrasztos mérésen mindkét oldali vesében multiplex angiomyolipomák láthatók, amelyek közül a legnagyobb a bal vesében lévő $58 \mathrm{~mm}$-es elváltozás

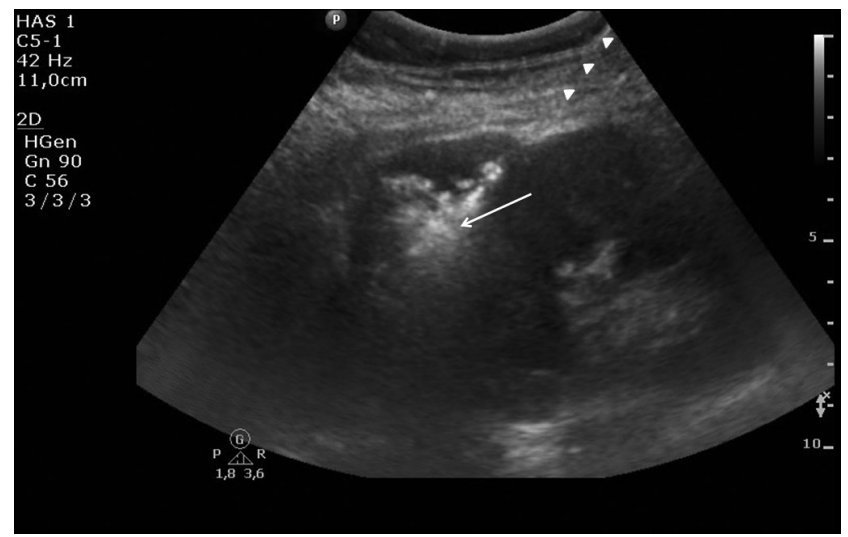

8. ábra

A bal vesében lévő angiomyolipoma ultrahangvezérelt RFA-kezelése. Megfigyelhető az elváltozás centrumába vezetett elekt róda (fehér nyílhegyekkel jelölve) és az ablatiós zónában a hőhatás eredményeként képződő gázbuborékok (fehér nyíllal jelölve)

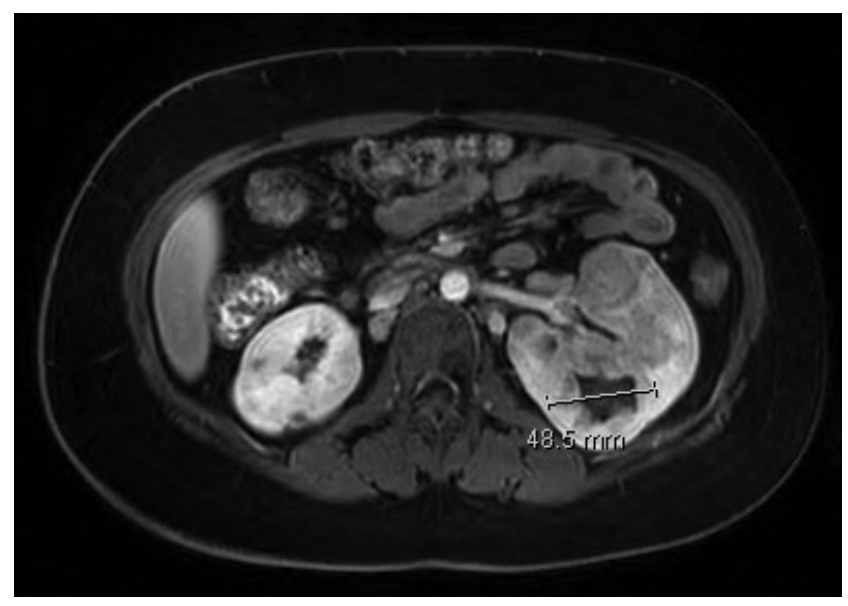

9. ábra Az ablatiót követő három hónapos kontroll-MR-vizsgálat kont rasztos mérésén a kezelt elváltozás méretbeli regressziója és a centrumában kialakult necroticus terület figyelhető meg 
- szövettanilag jóindulatú szolid vagy túlnyomóan szolid göbök, ahol a benignitást két külön FNAB igazolta;

- a göb jelentős panaszt (idegentest-érzés, nyaki diszkomfort, fájdalom) okoz a betegnek;

- kifelé domborodó göbök, amelyek esztétikai zavart okoznak;

- jelentősen növekvő göbök (50\% térfogat-növekedés egy év alatt);

- a betegnek jelentős lelki terhet jelent a jóindulatú göb rendszeres kontrollja, a félelem a napi életében hátráltatja;

- ha a beteg visszautasítja a mútétet, esetleg társult betegségei vagy többszörös nyaki operációi miatt a mútét nem kivitelezhető.

A beavatkozást kizáró okok közt említendő:

- ellenoldali hangszalag-rendellenesség,

- jelentős véralvadási zavar,

- súlyos szív- vagy tüdőbetegség.

\section{Negyedik beteg}

Az 56 éves nőbeteg jóindulatú elváltozások miatt többszörös pajzsmirigy-reszekción esett át. A residualis pajzsmirigy jobb lebenyében ultrahangvizsgálat során több 1-3 cm-es, részben meszes, hypervascularizált göböt írtak le (10. ábra). A göbökből vett vastagtü-biopsziás mintákban a szövettani vizsgálat során malignitás nem igazolódott. 2014 októberében a legnagyobb méretú göb RFA-kezelésére került sor (11. ábra). A kezelést követő kontroll-ultrahangvizsgálatok az ablált göb teljes devascularisatióját és jelentős méretbeli regresszióját mutatták (12. ábra). A tumortérfogat 32,1\%-kal csökkent, míg a halmozást mutató térfogat $100 \%$-os csökkenést mutatott.

\section{Megbeszélés}

A jóindulatú tumorok hőablatiós kezelése az elmúlt évtizedben vált elterjedtté a világon. Hazánkban eddig csak néhány centrumban végeztek ilyen beavatkozásokat, jelentősebb hazai tanulmány ebben a témában eddig nem jelent meg. Általánosságban igaz, hogy a jó- és rosszindulatú daganatok thermoablatiós technikákkal történő kezelése csaknem megegyezik egymással. Amellett, hogy a módszer adott, a rosszindulatú daganatokkal szerzett gyakorlati tapasztalatok segítik az intervenciós radiológust, hogy a már ismert eszközt benignus szöveti természetû daganatok esetén is alkalmazza. Ez utóbbi elváltozások esetében a környező ép szöveteket is kímélhetjük a „Primum nil nocere!” elvét is szem előtt tartva, hiszen nem feltétlenül köt minket az az önmagunkkal szemben támasztott (és rosszindulatú daganatok esetében egyébként jogos) elvárás, hogy minden daganatos szövetrészletet elpusztítsunk. Irodalmi adatok alapján az ablatiós kezelések legfontosabb előnyei közé tartozik az alacsony

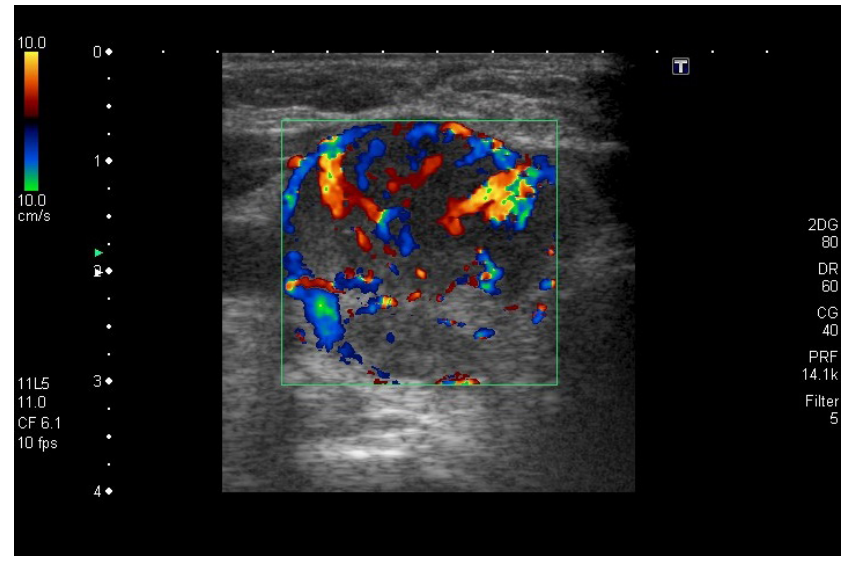

10. ábra A pajzsmirigy jobb lebenyében Doppler-ultrahangvizsgálattal egy hypervascularizált göb látható

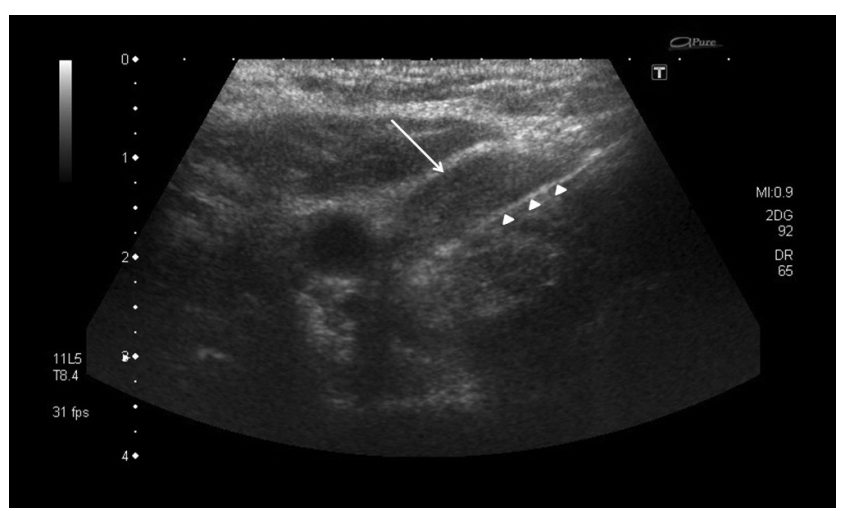

11. ábra | Pajzsmirigygöb (fehér nyíllal jelölve) ultrahangvezérelt rádiófrekvenciás ablatiója. Megfigyelhetô az elváltozás centrumába vezetett ablatiós tű (fehér nyílhegyekkel jelölve) és a körülötte képződő gázbuborékok

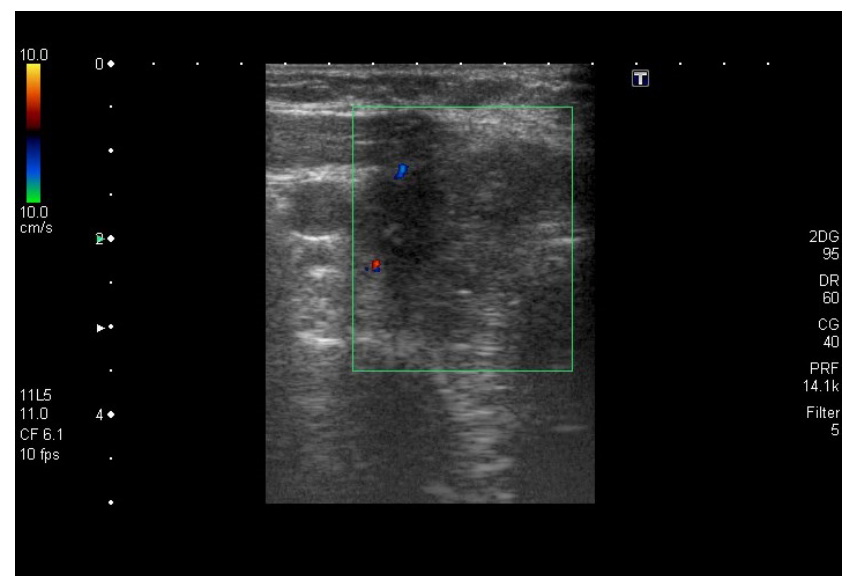

12. ábra

A másfél éves kontroll-ultrahangvizsgálat az RFA-val kezelt immár devascularizált - pajzsmirigygöb méretbeli regresszióját mutatja. A képleten belül Doppler-jel nem volt detektálható

szövődményráta, a jobb kozmetikai eredmény, valamint a lényegesen rövidebb lábadozási idő.

Az eljárás jelentőségét az adja, hogy olyan betegek esetében is kezelési alternatívát jelent, akiknél a sebészi kezelés ellenjavallt vagy akik nem egyeznek bele a nyitott mútétbe. Célkitüzésünk az volt, hogy megvizsgáljuk a 
1. táblázat $\mid$ A kezelt elváltozások teljes, illetve halmozást mutató térfogatának csökkenése

\begin{tabular}{lcc}
\hline & Térfogatcsökkenés (\%) & $\begin{array}{c}\text { Halmozó térfogat } \\
\text { csökkenése }(\%)\end{array}$ \\
\hline Haemangioma & 64 & 95 \\
Haemangioma & 29,9 & 98 \\
Haemangioma & 16,1 & 98 \\
Angiomyolipoma & 28,7 & 38,3 \\
Angiomyolipoma & 25,4 & 45,4 \\
Pajzsmirigygöb & 32,1 & 100 \\
\hline Átlag & 32,7 & 75,3 \\
\hline
\end{tabular}

klinikánkon végzett beavatkozások eredményességét és regisztráljuk az esetlegesen fellépő szövődményeket.

A klinikánkon végzett beavatkozások esetében a kezelt tumorok átlagos térfogatcsökkenése 32,7\% volt. A legnagyobb mértékű térfogatcsökkenést egy nagyméretü májhaemangioma MWT-kezelése során sikerült elérni (64\%), azonban mivel az egyes páciensek esetében az utánkövetési idők különböztek, ezért a beavatkozások egymáshoz viszonyított sikerességét ily módon nem lehet pontosan megítélni. Nemzetközi irodalmi források alapján óriás-májhaemangiomák MWT-kezelése után 62\%-os átlagos térfogatcsökkenés volt kimutatható [26]. $\mathrm{Az}$ intézetünkben kezelt vese-angiomyolipomák esetében a térfogatcsökkenés 25,4 , illetve $28,7 \%$ volt, amely elmarad a nemzetközi irodalomban fellelhető 47\%-os csökkenéstől [27]. A leírt különbséget viszont magyarázhatja, hogy míg esetünkben a kezelést követő kontrollvizsgálat hat hónappal a beavatkozást követően történt, addig az idézett tanulmányban az átlagos utánkövetési idő 23,1 hónap volt. A klinikánkon RFAval kezelt pajzsmirigygöb térfogata $32,1 \%$-kal csökkent, amely beleesik az irodalomban leírt 22-77\%-os intervallumba [28]. A kezelés hatására az elváltozások kontrasztanyag-halmozása is csökkent. A kontrasztanyag-halmozást mutató átlagos tumortérfogat-csökkenés 75,3\% volt. A legnagyobb mértékű halmozó térfogat csökkenést egy jóindulatú pajzsmirigygöb RFA-kezelésekor sikerült elérni, amelynél a kontrollvizsgálatok teljes devascularisatiót mutattak (1. táblázat). Eredményeink értékelésénél figyelembe veendő, hogy a képalkotó vizsgálatok elemzése retrospektív módon történt, az egyes pácienseknél eltérő modalitású kontrollvizsgálatokra került sor.

Szövődmény egyik beavatkozásnál sem lépett fel, tapasztalataink szerint az ablatiós kezelés biztonsággal alkalmazható a fentiekben bemutatott benignus szöveti természetü daganatok esetében. A radiológiai intervención átesett páciensek rövidebb kórházi bennfekvést igényeltek, néhány nappal a beavatkozás után visszatértek megszokott életritmusukhoz és mindezt lényegesen jobb kozmetikai eredménnyel tehették, mintha nyitott mütéten estek volna át. Fontos emellett megjegyezni, hogy az általunk bemutatottak csak egy részét reprezentálják a hőablatióval kezelhető jóindulatú eltéréseknek.

A hőablatiós technikák a jóindulatú tumorok kezelésének biztonságos és hatékony alternatívái. Nagyon fontos azonban, hogy a hatékonyság növelése mellett a szövődmények lehetőségét minimalizáljuk, ehhez körültekintő tervezés és gyakorlott intervenciós radiológus együttese szükséges. A késóbbiekben nagyobb betegszám és prospektív randomizált vizsgálatok esetén bízunk benne, hogy jól mérhetővé válik a hatékonyság, a biztonság, az ár/érték arány és az életminőség javulása. Az ilyen típusú intervenciók finanszírozása megfontolandó, mivel a hozzájuk kapcsolódó kiadások - noha ez további pontos számítást igényel - a nyitott mütétek költségeivel összevethetők.

Anyagi támogatás: A közlemény megírása, illetve a kapcsolódó kutatómunka anyagi támogatásban nem részesült.

Szerzői munkamegosztás: D. P. Á., D. A.: A vizsgálat lefolytatása. K. D. Á.: Adatgyưjtés, irodalomkutatás. D. P. Á., D. A., K. D. Á.: A kézirat megszövegezése. A cikk végleges változatát mindhárom szerző elolvasta és jóváhagyta.

Érdekeltségek: A szerzőknek nincsenek érdekeltségeik.

\section{Irodalom}

[1] Dodd, G. D. 3rd, Soulen, M. C., Kane, R. A., et al.: Minimally invasive treatment of malignant hepatic tumors: at the threshold of a major breakthrough. Radiographics, 2000, 20(1), 9-27.

[2] Van Vledder, M. G., van Aalten, S. M., Terkivatan, T., et al.: Safety and efficacy of radiofrequency ablation for hepatocellular adenoma. J. Vasc. Interv. Radiol., 2011, 22(6), 787-793.

[3] Engloner, L., Bánsághi, Z.: Interventional radiology procedures in the treatment of malignant liver tumours. [Intervenciós radiológiai módszerek alkalmazása a malignus májdaganatok kezelésében.] Folia Hepatologica, 1998, 3(1), 36-41. [Hungarian]

[4] Bánsághi, Z.: From image-guided biopsies to locoregional tumour treatments. [A képalkotó vezérelte mintavételektől a lokoregionális tumorterápiáig.] Orv. Hetil., 2015, 156(17), 698-705. [Hungarian]

[5] Poulou, L. S., Botsa, E., Thanou, I., et al.: Percutaneous microwave ablation vs radiofrequency ablation in the treatment of hepatocellular carcinoma. World J. Hepatol., 2015, 7(8), 10541063.

[6] Kaltenbach, T. E., Engler, P., Kratzer, W., et al.: Prevalence of benign focal liver lesions: ultrasound investigation of 45,319 hospital patients. Abdom. Radiol. (NY), 2016, 4l(1), 25-32.

[7] Buell, J. F., Tranchart, H., Cannon, R., et al.: Management of benign hepatic tumors. Surg. Clin. North Am., 2010, 90(4), 719-935.

[8] Terkivatan, T., Hussain, S. M., De Man, R. A., et al.: Diagnosis and treatment of benign focal liver lesions. Scand. J. Gastroenterol. Suppl., 2006, 41(Suppl. 243), 102-115.

[9] Kim, Y., Amini, N., He, J., et al.: National trends in the use of surgery for benign hepatic tumors in the United States. Surgery, 2015, 157(6), 1055-1064. 
[10] Petri, A., Höbn, J., Kókai, E. L., et al.: Surgery of benign liver tumors: indications for treatment: twenty years' experience. Hepatogastroenterology, 2008, 55(82-83), 592-595.

[11] Ott, R., Hohenberger, W.: Focal nodular hyperplasia and liver cell adenoma: operation or observation? [Fokale noduläre Hyperplasie und Leberadenoma: Operation oder Observation?] Zentralbl. Chir., 1998, 123(2), 145-153. [German]

[12] Fittschen, A., Wendlik, I., Oeztuerk, S., et al.: Prevalence of sporadic renal angiomyolipoma: a retrospective analysis of 61,389 in- and out-patients. Abdom. Imaging, 2014, 39(5), 10091013.

[13] Orlova, K. A., Crino, P. B.: The tuberous sclerosis complex. Ann. N. Y. Acad. Sci., 2010, 1184, 87-105.

[14] Yamakado, K., Tanaka, N., Nakagawa, T., et al.: Renal angiomyolipoma: relationships between tumor size, aneurysm formation, and rupture. Radiology, 2002, 225(1), 78-82.

[15] Steiner, M. S., Goldman, S. M., Fishman, E. K., et al.: The natural history of renal angiomyolipoma. J. Urol., 1993, 150(6), 1782 1786

[16] Harabayashi, T., Shinohara, N., Katano, H., et al.: Management of renal angiomyolipomas associated with tuberous sclerosis complex. J. Urol., 2004, 171(1), 102-105.

[17] Kennelly, M. J., Grossman, H. B., Cho, K. J.: Outcome analysis of 42 cases of renal angiomyolipoma. J. Urol., 1994, $152(6$ Pt 1), 1988-1991.

[18] Dean, D. S., Gharib, H.: Epidemiology of thyroid nodules. Best Pract. Res. Clin. Endocrinol. Metab., 2008, 22(6), 901-911.

[19] Péter, F., Leövey, A., Nagy, V. E., et al.: Thyroid gland diseases. [A pajzsmirigy kórképei.] In: Leövey, A., Nagy, E., Paragh, Gy. (szerk.): Az endokrin és anyagcsere-betegségek korszerú gyakorlata. Medicina Könyvkiadó, Budapest, 2010. [Hungarian]

[20] Larijani, B., Pajoubi, M., Bastanhagh, M. H., et al.: Evaluation of suppressive therapy for cold thyroid nodules with levothyroxine: double-blind placebo-controlled clinical trial. Endocr. Pract., $1999,5(5), 251-256$.

[21] Orlacchio, A., Bolacchi, F., Chegai, F., et al.: Comparative evaluation of percutaneous laser and radiofrequency ablation in patients with HCC smaller than $4 \mathrm{~cm}$. Radiol. Med., 2014, $119(5)$, 298-308.

[22] Na, D. G., Lee, J. H., Jung, S. L., et al.: Radiofrequency ablation of benign thyroid nodules and recurrent thyroid cancers: consensus statement and recommendations. Korean J. Radiol., 2012, $13(2), 117-125$.

[23] Jeong, W. K., Baek, J. H., Rhim, H., et al.: Radiofrequency ablation of benign thyroid nodules: safety and imaging follow-up in 236 patients. Eur. Radiol., 2008, 18(6), 1244-1450.

[24] Spiezia, S., Garberoglio, R., Milone, F., et al.: Thyroid nodules and related symptoms are stably controlled two years after radiofrequency thermal ablation. Thyroid, 2009, 19(3), 219-225.

[25] Baek, J. H., Moon, W. J., Kim, Y. S., et al.: Radiofrequency ablation for the treatment of autonomously functioning thyroid nodules. World J. Surg., 2009, 33(9), 1971-1977.

[26] Ziemlewicz, T. J., Wells, S. A., Lubner, M. A., et al.: Microwave ablation of giant hepatic cavernous hemangiomas. Cardiovasc. Intervent. Radiol., 2014, 37(5), 1299-1305.

[27] Cristescu, M., Abel, E. J., Wells, S., et al.: Percutaneous microwave ablation of renal angiomyolipomas. Cardiovasc. Intervent. Radiol., 2016, 39(3), 433-440.

[28] Korkusuz, Y., Koblhase, K., Gröner, D., et al.: Microwave ablation of symptomatic benign thyroid nodules: energy requirement per $\mathrm{ml}$ volume reduction. RöFo Fortschr. Röntgenstr., 2016, 188(11), 1054-1060.

(Deák Pál Ákos dr., Budapest, Baross u. 23-26., 1082 e-mail: deak.akos@med.semmelweis-univ.hu)

\section{A rendezvények és kongresszusok híranyagának leadása}

a lap megjelenése előtt legalább 40 nappal lehetséges, a 6 hetes nyomdai átfutás miatt. Kérjük megrendelőink szíves megértését.

A híranyagokat a következő címre kérjük:

Orvosi Hetilap titkársága: Budai.Edit@akkrt.hu

Akadémiai Kiadó Zrt. 